\title{
Glucagon Deficiency Causing Severe Neonatal Hypoglycemia in a Patient with Normal Insulin Secretion
}

\author{
JOSTEIN VIDNES ${ }^{(3)}$ AND STEPHANIE (DYAS.ETER \\ Pediatric Research Institute, Rikshespitalet, University Hospital. (Os/o. Nornay
}

\begin{abstract}
Summary
In the presented patient glucagon secretion was not stimulated by hypoglycemia or by infusion of alanine, whereas insulin secretion responded normally to changes in blood glucose and alanine concentrations. The administration of exogenous glucagon evoked an abnormally strong and prolonged hyperglycemic response. Gluconeogenesis was severely impaired, but there was no accumulation of the main gluconeogenic precursors. This was explained by the deficiency of substrates for these precursors, and by shunting into other pathways than gluconeogenesis.

The hypoglycemia was easy to control neonatally, whereas the condition at 3 months of age was critical. Treatment with glucagon resulted in a clinical improvement already observed the first day, whereas blood glucose normalized in 2-3 days. After 1 week the improvement was striking. The prompt initial effect of glucagon was ascribed to increased lipolysis, the delayed glucose rise to an induction of gluconeogenesis. At reexamination the rate of gluconeogenesis had increased 3 times. Glucagon treatment caused significant increase in pyruvate, free fatty acids, and insulin, whereas the alanine concentration fell. The subcutaneous injection of $0.1 \mathrm{mg}$ zinc protamine glucagon per $\mathrm{kg}$ body weight resulted in a plasma level of about $900 \mathrm{pg} / \mathrm{ml}$ shortly after the injection, with a subsequent exponential fall. The $K$ value was $13.5 \% / \mathrm{hr}$.
\end{abstract}

A brother and a sister probably died from hypoglycemia, and the closely related Pakistani parents had a partly deficient glucagon secretion. An autosomal recessive inherited disorder is suggested.

\section{Speculation}

Congenital glucagon deficiency would be expected to cause hypoglycemia, but no such case has so far been well documented. In this paper a patient with severe, persistent, neonatal hypoglycemia caused by an isolated glucagon deficiency is presented. This and similar cases may provide valuable information about the physiologic role of glucagon.

Glucagon, the 29-amino acid hormone secreted by the a.: cells of the islets of Langerhans in the pancreas, is a most powerful stimulant of hepatic glucose production. Glucagon antibodies injected into fasted rats cause a marked fall in blood glucose concentrations (19), and birds made glucagon deficient die within hours from hypoglycemia (37). In contrast, man has not yet been proved to have an absolute requirement for glucagon. This paper presents a patient with an isolated glucagon deficiency. Treatment with exogenous glucagon was probably essential for his survival.

\section{(ASI RIPORT AND CIIINICAI. COURSI}

$A-B I$, a boy (birth weight $3810 \mathrm{~g}$, length $51 \mathrm{~cm}$ ), was born on September 25. 1975. 2 weeks later than expected, after an uneventful pregnancy. His Pakistani parents are close relatives. At the grandparent level brother and sister married sister and brother. and son and daughter from these two couples married each other. hecoming parents of the patient to be deseribed. The parents and a brother born in 197.3 are living in good health. whereas a sister and a brother, born in 1971 and 1972 . respectively, died in Pakistan at 4.5 months and 4 months of age. respectively. with symptoms closely resembling those of the patient. The parents were told that the children had hypoglycemia. The family came to Norwaly in 1974.

The patient was admitted to the Department of Pediatries, Rikshospitalet. ()slo, on his third day of life because of repeated attacks of convulsive movements in the upper extremities and cyanosis. He was hypotonic, with a weak cry. Blood glucose was $15 \mathrm{mg} / \mathrm{dl}$. and spinal fluid glucose $8 \mathrm{mg} / \mathrm{dl}$, whereas other routine laboratory findings were normal. including serum electrolytes and liver function tests. Blood ketone bodies were in the lower normal range.

Treatment was suceessfully started with glucose intravenously. and after a few days normoglyeemia was maintained on frequent feedings with extrat glucose. At 1 month of age the condition was still good, but single episodes with fasting symptomatic hypoglycemia were recorded. From 1.5-2 months of age scattered attacks of jittering were registered, and mean blood glucose values slowly decreased, despite intensive treatment with varying theratpeutic regimens. At 2.5 months he got convulsive attacks, and a previously normal HEG now suggested epileptogenic lesions. The attacks increased in frequency in spite of anticonvulsant treatment. At 3 months of age the condition became critical (Fig. 1). He was hypotonic, semicomatous, nearly continuously hypoglycemic, and an alarming number of seizures were registered. However, all efforts to treat the condition were without success, until glucagon was introduced at 3.5 months of age (Fig. 1).

Except for the addition of glucagon, treatment was unchanged. The first 5 days he received short acting glucagon, 0.1 mg i.m. 6 times daily. the reafter zinc protamine glucagon, 0.4 mg s.c. twice daily. The convulsions ceased abruptly (Fig. 1). After 1 day muscle tonus was definitely increased, preceding the increase in blood glucose, which gradually rose to normal values in 3 days. During the first days of treatment the patient was irritable and weeping, but after 1 week the clinical improvement was striking. There was good tonus, eye contact, and for the first time the patient was smiling.

After 3 weeks the glucagon injections were temporarily discontinued. Two days later blood glucose fell, and the next few days he again got attacks of hypoglycemia. The glucagon therapy was resumed and the patient was rapidly restored (Fig. 1).

In addition to glucagon the patient still needed extra glucose supply. without which blood glucose tended to fall. At 4.5 months of age FiEG was normal, and on discharge from hospital at the age of 5.5 months he was in good health with only slightly retarded psychomotoric development. The treatment was continted after discharge, but considering the severe hypoglycemia 


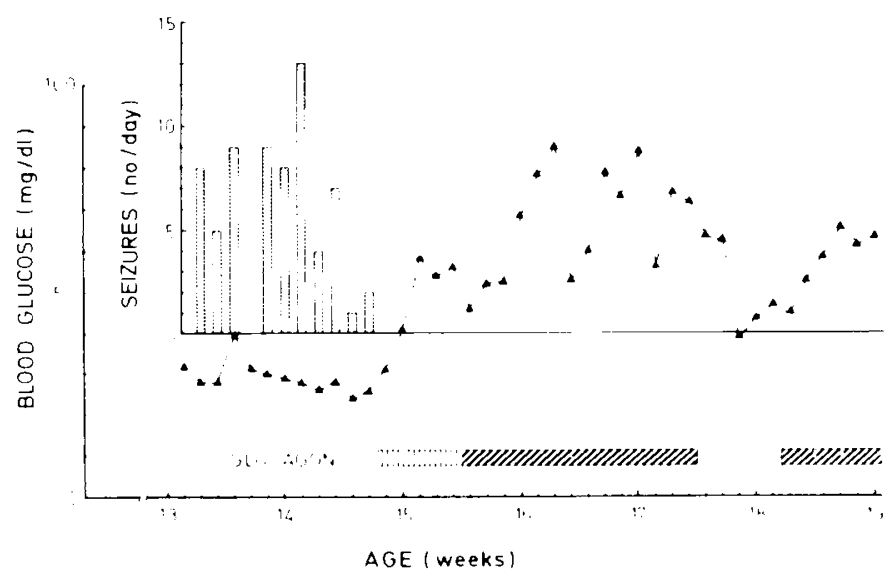

Fig. 1. The effect of glucagon treatment on mean hlood glucose and the number of seizures registered per dayg. Horizontal hars: short acting glucagon indicated by vertical cross hatching, zinc protamine glucagon hy oblique cross hatching. Vertical hars: numbers of seizures per day.

before glucigon treatment. and because of difficult social conditions at home. we were not tooconfident with respect to the long term prognosis.

\section{MATERIALS AND METHODS}

Short acting glucagon and zine protamine glucagen were obtained from Novo Industri $\mathrm{A} / \mathrm{S}$. Denmark. The first batches of zinc protamine glucagon were generous gifts. L-|U-" C $\mid$ Alanine was purchased from the Radiochemical centre. Amersham. Enzymes used in the analyses were purchased from Sigma Chemical Company.

Plasma was obtained from heparinized venous blood which was immediately put into an ice hath and separated by centrifugation at $4^{\circ}$. To prevent degradation of glucagon. Trasylol (50) K.I.E. $/ \mathrm{ml}$ ) was added to blood intended for glucagon analysis.

Blood glucose was determined by the method of Hultman (26). Plasma alanine and pyruvate were analyzed microfluorometrically by a slight modification of the method of $k$ arl et al. (27). Free fatty acids were determined as described by Trout et al. (45). and plasmat triglycerides according to the "Biochemica Test Combination" (Boehringer. Mannheim).

Amino acids in plasma and urine were determined with a conventional ion exchange procedure at the Department of Clinical Chemistry. Rikshospitalet. Oslo.

All investigations were performed with the parents consent.

\section{ANALYSLS OF HORMONES}

Plasma immunoreactive pancreatic glucagon was determined according to the method of Heding (25), and Novo Research Institute kindly supplied us with the pancreas glucagon specific antiserum K 964, glucagon for standards, and | ${ }^{125} \mathrm{I} \mid$ glucagon. All samples were assayed in triplicate. Recoveries of glucagon added to blood ranged from $89-109 \%$. and the interassaly variation of four determinations in a plasma sample containing 59 pg glucagon $/ \mathrm{ml}$ did not exceed the range of $\pm 7 \mathrm{pg} / \mathrm{ml}$. To determine the concentrations of nonspecific interfering plasma factors some samples were treated as described by Weir et al. (5.3). The glueagon values presented have not been corrected for possible nonspecific interference.

Immunoreactive insulin was determined by the method of Hales and Randle (22), with kits supplied by the Radiochemical Centre. Amersham. 17-Hydroxycorticosteroids were determined at the Division of Endocrinology. Medical Department B. Rikshospitalet. Oslo, and at the Hormone and Isotope Laborattory. Aker Hospital. Oslo. Catecholamines in urine were determined at the Department of Clinical ( hemistry, Rikshospitalet, Oslo.

\section{T()I.KRANCI: THSTS}

Secretion of pancreatic glucagon and insulin was evaluated by determining plasma concentrations in the basal state. and in response to infusion of 1 -alanine, a potent stimulus of glucagon secretion (39,54). After obtaining a fasting blood specimen. a solution of $\mathrm{L}$-alanine $(0.25 \mathrm{~g} / \mathrm{kg}$ body weight) was injected intravenously during 1-2 min. and blood sampled at intervals. The results were compared with the results of the same test in six patients (from 7 months 10.3 .5 years old) with hypoglycemia. where disorders of insulin and glucigon secretion had been excluded. Fasting blood glucose values prior to the test were similar in the patient and the control subjects (Fig. 2).

The standard glucagon tolerance test was performed by injecting $0.02 \mathrm{mg}$ glucagon $/ \mathrm{kg}$ body weight rapidly intravenously. and the intravenous glucose tolerance test by rapid injection of $0.5 \mathrm{~g}$ glucose $/ \mathrm{kg}$ body weight. The tests were performed in the morning after fasting periods varying between 5 and $12 \mathrm{hr}$. according to the tolerance of fasting.

\section{ASSAY OI (IILCONEOCIENLSIS}

The in rive method employed is based upon the appearance of radioactivity in glucose after intravenous injection of trace amounts of ${ }^{11}(-1 a b c l e d$ gluconcogenic substrates $(5 \mu \mathrm{Ci} / \mathrm{kg}$ body weight). Details of the method and its application are given elsewhere $(48-50)$. Briefly summarized. $\mathrm{L}-\left[\mathrm{U}-{ }^{1+} \mathrm{C}\right]$ alanine was rapidly injected intravenously. At intervals blood was sampled, and plasma was analyzed for the amount of radioactivity in alanine. lactate, and glucose by thin layer chromatography. The results are presented as percentages of the total amount of [14( Jalanine injected taking different distribution volumes into account. The incorporation of ${ }^{4} \mathrm{C}$ into glucose was used as an index of the overall gluconeogenesis. The four normoglyeemic patients used as control subjects have been described previously (48). The studies were performed with the parents' consent. and the ethical aspects of isotope studies have been discussed in previous publications $(48.49)$.

\section{STATISTLS}

The kevel of significance was calculated using Student's $t$-test for two means or the paired $t$-test, as judged appropriate. and a $P$ value of 0.05 was chosen as the significance level. $\mathrm{K}$ values for disappearance rates of injected compounds were calculated after computing the least squares fit for an exponential function of the form: $C_{1}=C_{10}{ }^{h l}$. where $C_{11}$ is the concentration at time zero. and $({ }$, the concentration at time $T$. The baseline values were subtracted. The insulin to glucagon molar ratio was calculated by the formula: [insulin $(\mu \mathrm{U} / \mathrm{ml}) /$ glucagon $(\mathrm{pg} / \mathrm{ml})] \times 2.3 .3$.

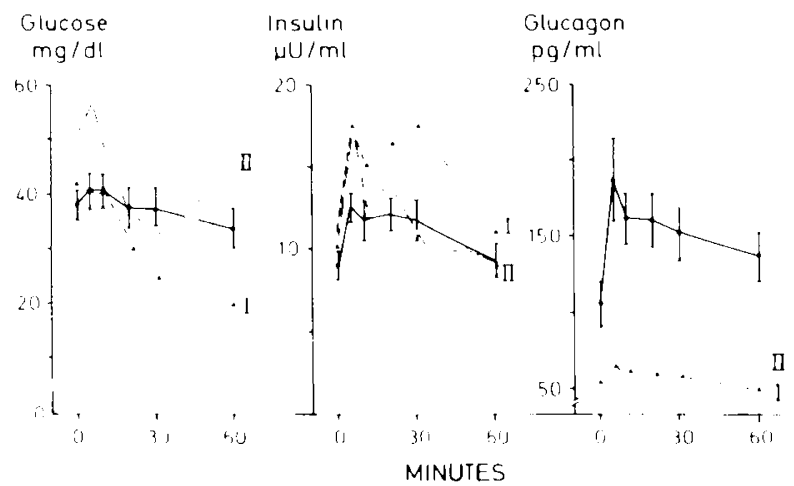

Fig. 2. Changes in blosed glucose, imsulin, and glucagon after the rapid infusion of alanine at $2 \mathrm{ro}$ time. The paticnt is compared with six hypoglycemic control subjects (mean \pm SE). l: before glucagon treatment. Il: after discontinuation of glacigon treatment for 4 dass. 


\section{RESULTS}

\section{SI:CRI:TION ()F (IIUUCAGON ANI) INSUI.IN}

Despite profoundly depressed blood glucose values, the basal plasma glucagon concentrations were low (Table 1). Moreover. 75\%: of the low glucagon concentrations apparently found could be shown to be caused by nonspecific plasma interference, not related to pancreatic glucagen. The basal insulin values, on the other hand, were normal.

The glucagon and insulin secretion was further studied after stimulation with alanine. The alanine tolerance test was performed on two occasions: I) at 2.5 months of age, before glucatgon treatment was started. and (I) at 4 months of age after discontinuation of glucagen treatment for + dilys. After the infusion of alanine plasma alanine concentrations increased to $30-40$ times baseline values after $5 \mathrm{~min}$, both in the patient and the control subjects, and there was no significant difference in the subsequent decrease. Nevertheless, the glueagon secretion in the patient did not increase, in contrast to all of the control subjects, where the rise was rapid and highly significant $(P$ 0.005 ) (Fig. 2). The insulin response, however, was brisk, with at maximal increase within the range of the control subjects. Blood glucose decreased in the patient in contrast to the control subjects.

Insulin secretion was also studied in response to glucose. An intravenous glucose tolerance test was performed when the pattient was 2 months old. The injected glucose disappeared rapidly, the $K$ value being $7.5 \% / m i n$, a high value at this age (24). However. plasma insulin increased only from $7 \mu \mathrm{U} / \mathrm{ml}$ in the basal state to $1+\mu \mathrm{U} / \mathrm{ml}$ after the injection of glucose. At 1.5 months of age the response to glucose given perorally wats studied (2.5 g/kg body weight). Basal blood glucose was $50 \mathrm{mg} /$ dl, fasting plasma insulin $7 \mu \mathrm{U} / \mathrm{ml}$. After glucose was given. blood glucose rose to $78 \mathrm{mg} / \mathrm{dl}$ at $30 \mathrm{~min}$, thereafter the glucose values oscillated around the basal value. An insulin maximum of $23 \mu \mathrm{U} / \mathrm{ml}$ was obtained $15 \mathrm{~min}$ after glucose was given.

17-0H-corticosteroids in urine and plasma and the response to ACTH stimulation and to the metyrapone test were normal. The excretion of catecholamines in urine was normal

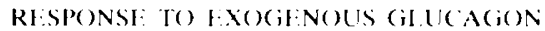

The response to exogenous glucagon was studied by a standard glueagon test. The test was repeated four times between 1 and 2 months of age. In Figure 3 the blood glucose response of the patient is compared with the responses of two hypoglycemic control subjects. In contrast to the normal responses of the controls, the hlood glucose increase in the patient was abnormally strong and sustained. With a long lasting and high plateau.

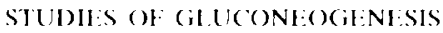

The patient's gluconeogenesis was measured twice: the first time the patient was 2 months 3 weeks old. $i$ e. . before the glacagon treatment was started; the second time he had been treated with glucagon for 2 weeks, and the study was performed $2 \mathrm{hr}$ after $0.4 \mathrm{mg}$ zinc protamine glucagon had been injected subcutaneously. The basal blood glucose value was $20 \mathrm{mg} / \mathrm{dl}$ before the first study, and $100 \mathrm{mg} / \mathrm{dl}$ before the second. The hasal plasmal alanine concentrations were 213 and $1+1 \mu \mathrm{mol} /$ liter. and the pyruvate concentrations 2.3 and $6.3 \mu$ mol/liter. respectively. These concentrations were minimally changed by the injection of tracer.

1.4 Alanine was injected intravenously as described. Before glucagon treatment the incorporation of "'C inte glucose was reduced to one-seventh that of the control subjects. pointing to a severe impaiment of gluconeogenesis (Fig. 4). After glucagon

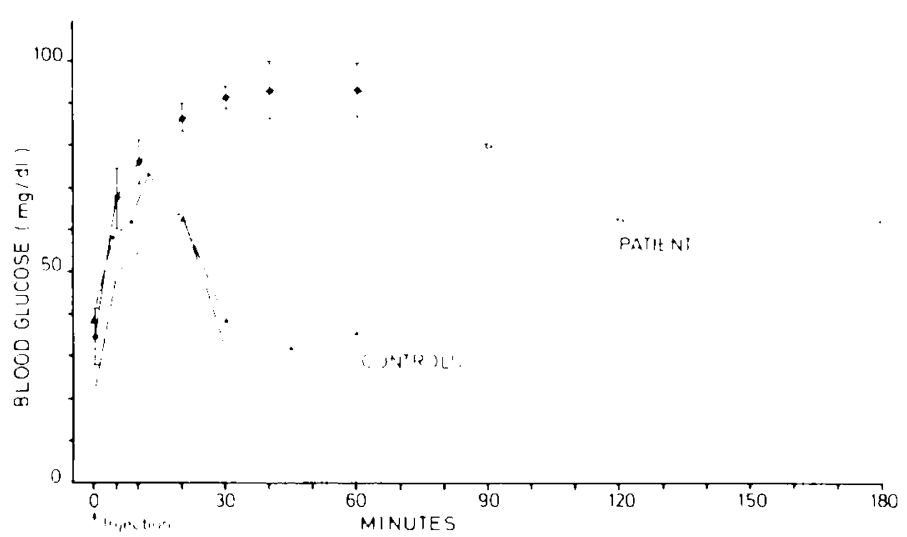

Fig. 3. Blond glucose during standard glucagon tolerance kests. four repeated glucagon tolerance tests (mean \pm Sf $) ;:$ ane of these tests continued up a 180 min. The patient is compared with two hypoglycemic control subjects with normat reponses to exogemose glucignom.

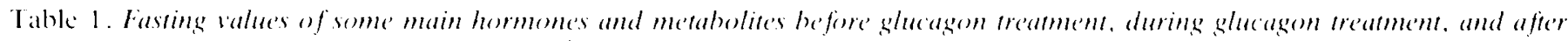
discontinuation of glucagen treatme'mt

\begin{tabular}{|c|c|c|c|c|c|c|c|c|}
\hline & $\begin{array}{c}\text { Cilucine : : : } \\
\text { mg/dl }\end{array}$ & $\begin{array}{l}\text { Insulin. } \\
\mu \mathrm{U} / \mathrm{ml}\end{array}$ & $\begin{array}{c}\text { (ilucagon, } \\
\text { pg/ml }\end{array}$ & $\begin{array}{l}\text { Insulin/ } \\
\text { gluciagon } \\
\text { ratio" }\end{array}$ & $\begin{array}{l}\text { Alaninc. } \\
\mu \text { mol/litcr }\end{array}$ & $\begin{array}{l}\text { Pyruvate. } \\
\mu \text { mol/liter }\end{array}$ & $\begin{array}{c}\text { FFA." } \\
\mu m() / l i t c r\end{array}$ & $\begin{array}{l}\text { Triglyecrides } \\
\mu \mathrm{mol} / \text { liter }\end{array}$ \\
\hline $\begin{array}{l}\text { I: Before glucigen treat- } \\
\text { ment }\end{array}$ & $\begin{array}{c}34.4+4.2 \\
(7) \\
1+11: \\
P-11.0(15\end{array}$ & $\begin{array}{c}9.6 \pm 1.5 \\
17) \\
1 \times 111: \\
P .11 .115\end{array}$ & 55 & $\begin{array}{l}5.28 \\
(2)\end{array}$ & $\begin{array}{c}213+13.6 \\
(7) \\
14.11: \\
P \quad 0.1125\end{array}$ & $\begin{array}{c}31+8.7 \\
(7) \\
1 \times .11: \\
P=11.115\end{array}$ & $\begin{array}{c}313+31 \\
(3) \\
I \cdots .11: \\
P=0.115\end{array}$ & $\begin{array}{c}730+122 \\
(6) \\
1 \mathrm{w.11} \\
\text { N.S. }\end{array}$ \\
\hline $\begin{array}{l}\text { II: During glucitgon truat- } \\
\text { ment }\end{array}$ & $\begin{array}{l}64.7 \pm 11.4 \\
\text { (6) } \\
\text { II is. III: } \\
\text { N.s. }\end{array}$ & $\begin{array}{c}1+.8 \pm 1.5 \\
(6) \\
11 \mathrm{vs.111:} \\
P-11.155\end{array}$ & $\begin{array}{l}398 \\
(2)\end{array}$ & $\begin{array}{l}(1.84 \\
(2)\end{array}$ & $\begin{array}{c}151+12.7 \\
(3) \\
11 \times .111: \\
1.0 .1025\end{array}$ & $\begin{array}{c}72 \pm 2.3 .1 \\
(3) \\
11 \mathrm{w.} \mathrm{III:} \\
\text { N.S. }\end{array}$ & $\begin{array}{l}5 x x \pm 8 x \\
\text { (3) } \\
11 \text { v. } 111: \\
\text { N.S. }\end{array}$ & $\begin{array}{c}518 \pm 48 \\
(.3) \\
\text { II v. } 111: \\
\text { N.S. }\end{array}$ \\
\hline $\begin{array}{l}\text { III: Discontinuation of glu- } \\
\text { (atgon treatment }\end{array}$ & $\begin{array}{c}53.7 \pm 3.7 \\
(3) \\
I \mathrm{v} .11 \mathrm{l}: \\
P=0.025\end{array}$ & $\begin{array}{c}9.7 \pm 11.9 \\
(3) \\
\text { I IS. III: } \\
\text { N.S. }\end{array}$ & $52+5 . x$ & $\begin{array}{l}+.35 \\
(.3)\end{array}$ & $\begin{array}{c}318 \pm 45.6 \\
(3) \\
1 \times 111: \\
P .0 .112\end{array}$ & $\begin{array}{c}40 \pm 19.0 \\
(3) \\
\text { I v. III: } \\
\text { N.S. }\end{array}$ & $\begin{array}{c}454 \\
(2) \\
1 \times .111: \\
P=0.05\end{array}$ & $\begin{array}{c}6.36 \pm 48 \\
(3) \\
\text { I } \mathrm{s} .111: \\
\text { N.S. }\end{array}$ \\
\hline
\end{tabular}

1 The values are given as mean \pm St:. Numbers of determinations in parcentheses.

$\because$ I $\mathrm{s}$. II: The values hefore (I) and during (II) glucagon treatment (etc.) tested for significance of difference.

"N.S.: not significant.

The glucigon values were not corrected for nompecific interference

Frec fatty acids 


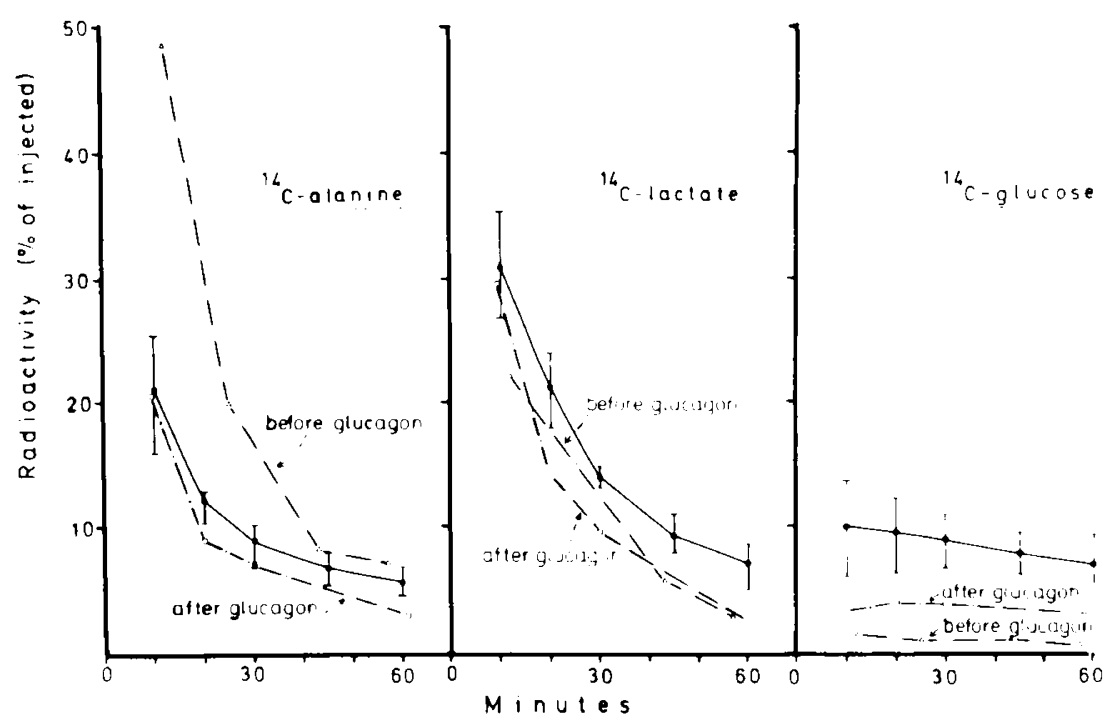

Fig. 4. Time course for the incorporation of "' $\mathrm{C}$ from labeled alanine into plasmal lactate and glucose. A tracer dose was rapidly injected intravenously at zero time. The values are presented as pereentages of the injected radioactivity. The patient was compared with the mean of four normoglycemic control subjects, the vertical bars showing the range. The patient was studied hefore glucagon treatment. and after being treated for 2 weeks. Zinc protamine glucagon was injected 2 hr hefore the last study.

treatment the amount of $14 \mathrm{C}$ incorporated into glucose was increased 3 times, but the amount was still below the range of the control subjects.

The disappearance of ${ }^{14} \mathrm{C}$ from plasma alanine was delayed before glucagon treatment, but normalized after treatment. In contrast, the amount of ${ }^{14} \mathrm{C}$ in lactate was close to that of the control subjects both before and after glucagon treatment.

\section{PLASMA AMINO ACIDS}

The plasma amino acids at 4 days of age were compared with the data of Brodehl and Gellissen (5). The concentrations of aspartate $(38 \mu \mathrm{mol} /$ liter $)$, serine $(203 \mu \mathrm{mol} /$ liter $)$, glycine $(323$ $\mu \mathrm{mol} /$ liter $)$, and methionine $(47 \mu \mathrm{mol} /$ liter $)$ were high, whereas there were low levels of alanine $(178 \mu$ mol/liter $)$. valine ( 71 $\mu \mathrm{mol} / \mathrm{liter})$. isoleucine $(7 \mu \mathrm{mol} / \mathrm{liter})$, and leucine $(40 \mu \mathrm{mol} /$ liter). The following amino acids were present in normal amounts: threonine, asparagine, glutamate, glutamine, proline, cystine, tyrosine, phenylalanine, ornithine, lysine, histidine, and arginine. In urine glycine was increased $(5.53 \mu \mathrm{mol} / \mathrm{mg}$ creatinine). At 3 months of age the amino acids in plasma had normalized. but the excretion of glycine in the urine was still high.

\section{EFFECTS OF GILUCAGON TREATMENT ON FASTING; VALUES OH} GLUCAGON. INSULIN, AND SOME MAIN METABOLITES

The mean fasting values of glucagon, insulin, and some main metabolites were compared before glucagon treatment, during glucagon treatment, and at the end of the period when glucagon treatment was discontinued (Table 1). The rise in blood glucose during treatment was highly significant $(P=0.005)$. Despite an increase in the insulin values. the insulin to glucagon molar ratio fell. There was a significant fall in plasma alanine. a well known effect of glucagon $(8,9)$, whereas pyruvate rose. A decrease in plasma triglycerides was indicated, hut not statistically significant, whereas free fatty acids increased significantly. In the period when glucagon treatment was temporarily discontinued. the measured values tended to approach the pretreatment concentrations, except for alanine, which increased to values significantly higher than before treatment was started.

\section{KINETICS OF EXOGENOUS LONG ACTING GIUCAGION}

The patient, having no endogenous glucagon production. gave the opportunity to study the kinetics of exogenous longacting

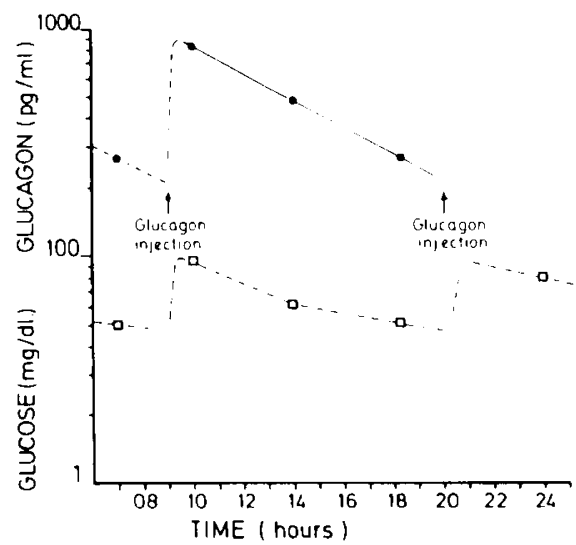

Fig. 5. Plasma glucagon and blood glucose after the subcutancous injection of zinc protamine glucigon (0.1 mg/kg body weight) at the time points indicited. The values are presented in a semilogarithmic plot. plasma glucagon; [־]: hlood glucose.

glucagon given subcutaneously. When the patient was 4.5 months old $0.1 \mathrm{mg}$ zine protamine glucagon $/ \mathrm{kg}$ hody weight was injected subcutaneously as shown in Figure 5 . In the semilogarithmic plot the glucagon values represented a straight line. and the pairs of data showed a good fit to the equation $C_{1}=C_{1}$. e 11 (see under "Materials and Methods"). The correlation coefficient (r) was close $t 01.00()$ and the correlation was highly significant $(P<0.001)$. The calculated disappearance rate, $\mathrm{K}$ value, was $1.3 .5 \% / \mathrm{hr}$. which implies that the glucagon concentration would fall from $935 \mathrm{pg} / \mathrm{ml}$ shortly after the injection to 186 $\mathrm{pg} / \mathrm{ml} 12 \mathrm{hr}$ after the injection.

The blood glucose values tended to parallel the glucagen concentrations in the semilogarithmic plot. It could further be shown (not displayed) that plasma alanine, and possibly pyruvate. were also correlated with the glucagon concentration. whereas there was no correlation with the measured insulin values.

\section{STUDIES IN PARENTS}

Since the case history suggested an inherited disorder, the parents were studied in the fasting state and during an alanine tolerance test.

The mother received $0.22 \mathrm{~g}$ and the father $(0.24 \mathrm{~g} \mathrm{I}$-alanine/ $\mathrm{kg}$ 
NEONATAL HYPOGLYCEMIA IN GI.UCAGON DEFICIENCY

Table 2. Plasma glucagon, insulin, and glucose concentrations in parents of patient'

\begin{tabular}{|c|c|c|c|c|c|c|}
\hline \multirow[b]{2}{*}{ Subjects } & \multicolumn{2}{|c|}{ Glucagon, $\mathrm{pg} / \mathrm{ml}^{2}$} & \multicolumn{2}{|c|}{ Insulin, $\mu \mathrm{U} / \mathrm{ml}$} & \multicolumn{2}{|c|}{ Glucose, $\mathrm{mg} / \mathrm{dl}$} \\
\hline & Basal & Maximal increment ${ }^{3}$ & Basal & Maximal increment & Basal & Maximal increment \\
\hline Healthy controls & $89 \pm 10$ & $108 \pm 12$ & $10 \pm 1$ & $14 \pm 2$ & $78 \pm 2$ & $6 \pm 1$ \\
\hline Patient's mother & 44 & 49 & 15 & 14 & 85 & -7 \\
\hline Patient's father & 56 & 36 & 12 & 11 & 94 & -18 \\
\hline
\end{tabular}

1 The results are presented as mean \pm SE. The parents were studied in the basal state and after an alanine infusion.

${ }^{2}$ The glucagon values were not corrected for nonspecific interference.

${ }^{3}$ Maximal increment above basal values.

4 The results in 21 control subjects published by Donowitz et al. (10)

body weight. The results were compared with those published by Donowitz et al. (10). who performed a similar alanine tolerance test in 21 healthy nonobese voluntecrs, but with $0.15 \mathrm{~g} \mathrm{I}$.alanine/kg body weight. The analytic methods used differed from those of the present study. With these reservations in mind, it may be inferred from Table 2 that the differences with respect to insulin were minor. whereas the glucagon values in the basal state appeared lower in the parents than in the control subjects. The increment in glucagon secretion after stimulation of the $\alpha$. cells with alanine appeared to be blunted. Furthermore, there was no increase in the blood glucose values, but a late decrease. most apparent in the father.

\section{DISCUSSION}

The present report demonstrates clearly that glucagon deficiency will cause severe hypoglyeemia in a patient with normal insulin secretion.

The diagnosis of glucagon deficiency was not based mainly on low basal glucagon concentrations. but on the lack of response to hypoglycemia and alanine infusion, both known to be potent stimulators of glucagon secretion $(16,39,40,54)$. This lack of response wats demonstrated on repeated occasions. and contrasted the highly significant increase in the control subjects (Fig. 2 ). Glucagon deficiency thus hats to be included in the list of known causes of neonatal persistent hypoglyeemia, and should be sought for in all cases of hypoglycemia with obscure etiology. Moreover. regarding the good results of treatment, glucagon secretion should be examined at an early stage.

The disorder was congenital, and the family history and the findings in the parents suggest an inherited disorder with an autosomal recessive mode of inheritance. We have no pancreas biopsy of the patient and do not know the morphologic correlate to the disorder. but the normal insulin secretion points to a defect specifically involving the pancreatic $\alpha_{2}$ cells, leaving the $\beta$ cells unaffected. The existence of extrapancreatic $\alpha_{2}$ cells is disputed in man $(3,38)$ in contrast to other species such as the $\operatorname{dog}(34,51)$.

The biologic role of glucagon is to ensure, in concert with insulin, a steady supply of substrates under a wide range of physiologic conditions. The molar ratio of insulin to glucagon seems to be more important than the absolute concentration of either $(46)$. In the patient described the most significant effect of the unopposed insulin action wats the severe hypoglycemia, the cause of which might be deficiencies in three main metabolic processes providing energy-yielding substrates, namely gluconeogenesis, glycogenolysis, and lipolysis (31).

Gluconeogenesis normally starts after birth $(1.3,2.3)$ by the normal postnatal increase of glucagon $(17,43)$ inducing the hepatic enzyme phosphoenolpyruvate carboxykinase, one of the key enzymes of gluconeogenesis $(7,23,42)$. In later life glucagon is an important stimulator of gluconeogenesis in situations of glucose need $(8,12,13)$. The severely impaired gluconeogenesis in the presented patient was considerably improved by glucagon treatment, but not quite normalized (Fig. 4). However, high blood glucose concentrations have been shown to depress gluconeogenesis in both animals and in man $(15,35)$, and blood glucose in our patient rose 5 -fold from the first to the second study. during the second study exceeding the mean blood glucose values of the controls by more than $40 \%(48)$.

Glucagon is a potent hepatoglycogenolytic atgent (31). whereas insulin stimulates the synthesis of glycogen. In our patient the atonormally strong and prolonged hyperglycemia provoked by the standard glucagon tolerance test suggested great deposits of glycogen in the liver, caused by the unopposed insulin action (Fig. 3). The response further indicated excessive sensitivity to exogenous glucagon, as would be expected in a patient with no glucagon production of his own.

Glucagon stimulates lipolysis and ketogenesis (29,32). thereby liberating free fatty acids, glycerol, and ketone hodies. Ketone bodies may largely substitute for glucose as fuel for the brain $(11,+1)$, and free fatty acids are a main energy source for the liver. thus being a prerequisite for the energy-requiring process of gluconeogenesis (6). Furthermore, glycerol is rapidly converted to glucose in the liver (1). In our patient the concentrations of free fatty acids and ketone bodies were in the lower normal range before glucagon treatment, and could not compensate for the low blood glucose concentrations. The glucagon treatment caused a significant rise in free fatty acids (Table 1 ), thus providing the patient with additional energy-yielding substrates.

Main precursors for gluconeogenesis are lactate and the glucogenic amino acids, the majority of these precursors flowing through pyruvate $(13,14)$. In our patient the concentrations of lactate, pyruvate, and alanine were low despite the severely impaired gluconeogenesis. Although the other glucogenic amino acids tended to be high. alanine is the major precursor in this context (14). However, in contrast with the other glucogenic amino acids, alanine is chiefly synthesized de nolo from pyruvate in extrahepatic tissues by the transamination of pyruvate (14). Low concentrations of pyruvate limit substrate availability for this transamination. Reduced protein catabolism caused by the glucagon deficiency $(9,14)$ decreases the amount of amino groups to be transaminated. The low levels of pyruvate and lactate were probably caused by the deficiency of glucose, their main precursor (28). Additionally, glucagon inhibits pyruvate oxidation $(8,13,21)$. Consequently, glucagon deficiency would be expected to increase oxidation of pyruvate and thereby reduce the levels of gluconeogenic precursors.

The hypoglyecmia in the presented patient was initially casy to control. whereas the condition at 3 months of age was virtually resistant to conventional treatment. Varma et al. (47) demonstrated that dogs under 55 days of age were less sensitive to insulin action than were adult dogs. The disappearance rate of glucose in man is low the first neonatal days, increases to a maximum between 4 and 12 months of age, and then slowly decreases towards adult levels (24). A decreased glucose utilization during the first weeks of life might explain the clinical course of our patient.

Glucagon treatment resulted in a definite clinical improvement the first day of treatment, 2 days before blood glucose had normalized. This observation maty be explained by the lipolytic effect of glucagon. rapidly increasing the concentrations of free fatty acids and ketone bodies, whereas normalization of blood 
glucose depends on the induction of gluconeogenesis. This induction has been shown to have a lag period of $2-4$ days in man $(1.3,3.3,4.3)$.

Our patient was treated with zinc protamine glucagon, administered subcutaneously in the amount of $0.1 \mathrm{~m} / \mathrm{kg}$ body weight twice daily. Plasma glucagon is normally low and shows small fluctuations during the day (44). The plasma concentrations in our patient showed great variations. The mean glucagon concentrations. however, might not be far from physiologic, as concentrations in the portal circulation are higher than in peripheral blood (2), and glucagon is mainly acting on the liver. Too high plasma glucagon concentrations should be avoided. as they may cause harmful catabolic effects (30).

Hypoglyeemia in children has heen attributed to glucagon deficiency on several occasions $(18,20,52)$ since the original description by McQuarrie et al. (36) of presumed $\alpha$ cell deficiency in familial infantile hypoglycemia. These reports were based upon histologic evidence of a reduced number of pancreatic $\alpha$ cells, but did not take into account that only a small proportion of the $\alpha$ cells is comprised of $\alpha_{2}$ cells, being alone capable of secreting glucagon. and the deficiencies were not verified by measurements of pancreatic glucagon. So far a deficiency of immunoreactive pancreatic glucagon in hypoglycemia has been reported only once in a young adult mate (4). However, in this case. there was deficient secretion of both insulin and glucagen. This complicated the clinical picture. Furthermore, similar deficiencies are seen in unspecific islet cell destructions (10).

\section{CONCI.USION}

A Pakistani boy with a family history of infant deaths was admitted shortly after birth because of hypoglyeemic seizures. After some initial improvement. his condition became critical with recurrence of the seizures. Despite severe hypoglyeemia. basal glucagon values were low, and did not increase after alanine infusion. Insulin secretion was normal. Gluconeogenesis was severely impaired. The hyperglyeemic response to a standard glucagon tolerance test was abnormally strong. Treatment with glucagon resulted in immediate cessation of the seizures. whereas blood glucose increatsed to normal values in 3 diays. Gluconeogenesis increased 3-fold. After 1 week of glucagon treatment the clinical condition had strikingly improved. and after 5 weeks a previously abnormal EEG had normalized. Discontinuation of glucagon treatment resulted in a relapse. The closely related parents also had low glucagon values, responding weakly to stimulation with alanine. An autosomal recessive inherited disorder is suggested. This is the first case described with normoinsulinemic glucagon deficiency as the cause of persistent neonatal hypoglycemia.

\section{RHFIRENCES AND NOTHS}

1. Aikatwa. T., Matsutakat, H. Takezawa, K., and lshikatwa, H.: (iluconeogenesis and amino acid metabolism. I Comparison of various precursors for hepatic gluconeogenesis in vivo. Biochim. Biophys. Acti, 279: 234 (1972)

2. Alford, F.P., Bloom, S. R.. Naharro, J. D. N.. Hall, R., Besser, G. M.. Coy D. H.. Kastin. A. J.. and Schally, A. V.: (ilucatgen control of fasting glucose in man. lancet, ii: 974 (1974).

3. Barnes, A. J., and Bloom. S. R.: Pancreatectemised man: A model for diabetes without glucagon. Lancet, i: $214(1976)$.

4. Bleicher. S. J., Levy, L. J., Zarowitz, H. and Spergel. (i.: Glucagon-deficient hypoglycemia: A new syndrome |Abstr.]. Clin. Res.. 18: 355 (1970)

5. Brodehl. J., and Gellisen, K.: Endogenous renal transport of free amino acids in infancy and childhood. Pediatries, $42: 395(196 x)$.

6. Cahill. G. F., Jr.: Starvation in man. New Lngl. J. Med.. 282: 668 (1970).

7. Cake, M. H. Yeung. D.. and Oliver. 1. T.: The control of postnatal hypoglycemia. (Suggestions hased on experimental ohervations in neonatal rats). Biol. Neonate. $18: 18.3(1971)$.

8. Chiasson, J. L., Liljenquist, J. E., Sinclair-Smith. B. C.. and Lacy, W. W. Gluconeogenesis from alanine in normal postaborptive man: Intrahepatic stimulatory effect of glucagon. Diahetes. 24: $574(1975)$.

9. Daniel, P. M., Pratt, O. E., and Spargo, E.: Release of amino acids from the muscles of normal and fasted rabbits following injection of glucagon. J. Physiol. (Lond.). 249: 48 P (1975).

10. Donowitz. M.. Hendler, R., Spiro, H. M., Binder, H. J., and Felig. P.:
Glucagon secretion in atcute and chronic pancreatitis. Ann. Infern. Med. 83: $778,(1975)$.

11. Drenick, F. J., Alvare\%, L. (C.. Tamasi, (i. ( .. and Brickman, A. S.: Resistance to symptomatic insulin reactions after fasting. J. Clin. Invest .. 5/:2757 (1972).

2. Eisenstein. A. B., Strack. 1.. and Steiner, A.: Glucagon stimulation of hepatic gluconeogenesis in rats fed a high-protein. carbohydrate-free diet. Metaholism, 23: $15(1974)$.

13. Exton. J. H.: (iluconeogenesis. Metabolism, 21: 945 (1972)

14. Felig. P.: The glucose-alanine cycle. Metabolism, 22: 179 (197.3).

15. Felig. P.. and Wahren. J.: Influence of endogenous insulin secretion on splanchnic glucose and amino acid metabolism in man. J. (lin. Invest., 50: $1702(1971)$

16. Gerich, J. F.. Schneider. V., Dippe. S. E.. I Ianglois, M., Noacco, C.. Karam, J. H. and Forsham. P. H.: (haracterization of the glucagon response to hypoglycemiat in man. J. Clin. Endecrinol. Metab., 38: 77 (1974)

17. Girard. J., Bal. D., and Assan, R.: Glucagon secretion during the early postnatal period in the rat. Horm. Metab. Res.. 4: 168 (1972).

18. Gotlin. R. W.. and Silver. H. K.: Neonatal hypoglycatemia. hyperinsulinism, and absence of pancreatic alpha-cells. Lancet, $i: 1346(1970)$.

19. (irey, N.. McGugan. J. F... and Kipnis, D. M.: Neutralization of endegenous glucagon by high titer glucagon antiserum. Fndocrinology. 80: 1.383 (1970).

20. Crollmann, A.. McCaleh. W. F., and White, F. N.: (ilucagon deficiency an a cause of hypoglyeemia. Metatholism, 1.3: $6860(1964)$

21. Hagg. S. A.. Taylor, S. I., and Ruderman. N. B.: Glucose metabolism in perfused skeletal muscle: Pyruvate dehydrogenase activity in starvation. diabeter and exercise. Biochem. J., 158: $2033(1976)$.

22. Hale ( N and Randle, P. J.: Immunoassaty of insulin with insulin-antibudy precipitate. Biochem. J., 88: $1.37(196,3)$

23. Hanson, R. W.. Reshef, L... and Batlard. J.: Hormonal regulation of hepatic P-enolpyruvate carboxykinase (GiP) during development. Fed. Proc... 34: $166(1475)$.

24. Hattingherg. H. M. ven, (iladtke. H... and I)ost. F. H.: Die Differenzierung der pathologischen Kohlenhydrattoleranz. Dtsch. Med. Worchenschr., 4.5: $349(1970)$.

25. Heding. I. G.: Radioimmunological determination of pancreatic and gut glucagon in plasma. Diabetologia, 7: 10 (1971).

26. Hultman. F.: Rapid specific method for determination of aldositecharides in body fluids. Nature, $183: 108(1959)$

27. Karl. I. F.. Pagliara. A. S.. and Kipnis, D. M.: A microfluorometric enzymatic assay for the determination of alanine and pyruvate in plasma and tissues. J. 1.ab. Clin. Med.. 80): 434 (1972).

28. Kreisherg. R. A.: (ilucose-lactate inter-relations in man. New Fingl. I. Med. 28: $132(1972)$.

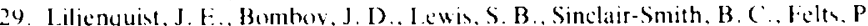
W. I acy, W. W . Crofford, (). B., and liddle, (; W . F Ffects of glucagon on lipolysis and ketogenesis in normal and diabetic men. J. Clin. Invest. . 5.3: $190(1974)$.

30. Matlinson, C. N. Bloom, S. R. Warin, A. P., Salmon, P. R., and Cox, B.: A glucagenoma syndrome. I ancet, ii: $1(1974)$.

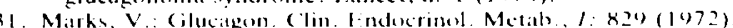

32. Marks, V.: Glucagon and lipid metabolism in man. Postgrad. Med. J. \$4: 615 (147.3).

33. Marsac. C.. Saudubray. J. M., Moncion. A. and I.eroux, J. P.: Development of gluconcogenic engymes in the liver of human newhorm. Biol. Neomate, $28: 317(1476)$

34. Mashiter. K.. Harding. P. E., (hou. M. Mashiter, (;. D.. Stout. J.. Diamond. D.. and Ficld, J. B.: Persistent pancreatic glucigon but not insulin response to arginine in pancreatectomized dogs. Endocrinology. 96: 678 $(1975)$.

35. MCDaniel. H. (;.: Acute suppression of hepatic gluconeogenesis hy glucoese in the intact animal. Amer. J. Physiol. 224: 1564 (1975).

36. McOuarric, I. Bell. E. T. Zimmermann. B.. and Wright. W'. S.: Deficiency of alpha cells of pancreas as possible etiological factor in familial hypoglycemosis. Fed. Proc. 9: 3.37 (1950).

37. Mikami. S.-1.. and Kazuyuki. ().: (ilucagon deficiency induced hy extirpation of alpha islets of the fowl pancreas. Endecrinology. 71 : $464(1962)$.

38. Müller W. A. Brennan, M. F. Tan. M. H. and Aoki, T. T.: Studies of glucagen secretion in pancreatectomized patients. Diabetes. 23: 512 $(1974)$.

39. Muller. W'. A. Falouna, (i. R. and Unger. R. H.: The effect of alanine on glucagon secretion. J. (lin. Invest. 56): 2215 (1971)

40. (Ohnedar. A.. Aguilar-Parada, L.. Fincentraut, A. M.. and Unger. R. H Control of pancreatic glucagon secretion by glucose. Diahetes, IS: $1(1969)$.

41. ()wen. (). E... Morgan. A. P.. Kemp. H. G. Sullivan, J. M.. Herrera. M. (;. and (ahill. (. F.: Brain metaholism during fasting. J. Clin. Invest., 46: $1589(1967)$.

42. Raihï, N. ( . R., and I indros, K. ().: Development of some ensymes involved in gluconeogenesis in human liver. Ann. Med. Fxp. Biol. Fenn.. 47: 1th $(1964)$.

43. Sperling, M. A. Del amater, P. V. Phelpe, D. Fiser, R. H. (Ob. W. and Fisher. D. A.: Spentaneous and amino acid-stimulated glucagon secretion in the immediate postnatal period. J. (Clin. Invest.. 5.3: 1159 (1974)

44. Tasaka. Y.. Sckine, M.. Wakatsuki. M. (Ohgawara, H., and Shizume, K. Levels of pancreatic glucigon. insulin and glucose during twenty-four hours of the day in normal subjects. Horm. Metab. Res., 7: 205 (1975)

45. Trout, D. B.. Fstes. F. H.. Jr.. and Friedberg. S. J.: Titration of free fatty acids of plasma: A study of current methods and a new modification. i l.ipid. Res., 1: 194 (1960). 
46. Unger, R. H.: Alpha- and heta-cell interrelationships in health and discalse. Metaholism, 23: $581(1974)$.

47. Varma, S. Nickerson. H., Cowan. J. S.. and Hetenyi. (i.. Jr.: Homeostatic responses to glucose loading in newborn and young dogs. Metabolism. 22: $1367(1973)$

48. Vidnes, J.: Gluconengenesis in infancy and childhood. I. A method for the study of the in vivo gluconeogenesis from atanine and glycerol. Scand. J. (lin. Iah. Invest. 36: 347 (1976)

49. Vidnes, J., and Savik, (O.: Gluconeogenesis in infancy and childhood. II. Studies on the glucose production from alanine in three cases of persistent neonatal hypoglycalemia. Actal Pediat. Scand. 65: 247 (1976).

50. Vidnes. J.. and Sovik. ().: (Bluconeogenesis in infancy and childhood. III. Deficiency of the extramituchondrial form of hepatic phomphemolpyruvate carboxykinase in a catse of persistent neomatal hypoglycasemia. Actat Pediat. Scand $6.5: 307(1976)$.

51. Vranic. M., Pek. S., and Kawameri. R.: Increased "glucagen immunoreactivity" in plasma of totally depancreatized doge. Diabetes, $23.905(197+1)$

52. Wagner, T. Spranger. J.. and Brunck. H. J.: Kongenitater o-Zellmangel als
Ursache einer chronischen infantilen Hypoglykümie? Monatsschr, Kinder heilkd.. 117:236 $(196,9)$

53. Weir, (i. ('.. Turner, R. ('.. and Martin, 1). B.: (ilucagon radiommunoassaty using antinerum $30 \mathrm{~K}$ : Interference by plasmat. Horm. Metalh. Res. 5: 241 (197.3)

54. Wise, J. K.. Hendler. R., and Folig, P.: Fvaluation of alphat-cell function by infusion of alanine in normal. diabetic and obese subjects. New Engl. J. Med. 288: $487(1973)$

55 . This study was presented in part at the Furopean Society for Pediatric Re satreh. June 1976 . Rotterdam. Holland

56. This work was supported by Norske Kvinners Sanitetsforening. I)r. (). Sowik and Dr. (). Stokke are acknowledged for valuable criticism during the preparation of the manuscript.

57. Requests for reprints should be addressed (o: J. Vidnes, M1.D., Pediatric Research Institute, Rikshospitalet, (Oslo 1 (Norway)

$5 x$. Received for publication November 29, 1976.

59. Accepted for publication Fehruary 9. 1977
Arginaso

argininosuccinate synthetase homocitrullinuria hyperammonemia hyperlysinemia

\title{
Periodic Hyperammonemia, Hyperlysinemia, and Homocitrullinuria Associated with Decreased Argininosuccinate Synthetase and Arginase Activities
}

\author{
HIDFAKI SOGAWA, KAZUHIKO OYANAGI. ANI) TOORU NAKAO \\ Department of Pediatrics, Sapporo. Medical College'. Japan
}

\section{Summary}

An 18-year-old mentally and physically retarded male with periodic hyperammonemia is described. Levels of lysine and citrulline in his serum and those of blood ammonia were elevated and daily excretions of homocitrulline in his urine were strikingly high on an ordinary diet. With a decrease in protein intake to 1.5 $\mathrm{g} / \mathrm{kg}$ body weight/day, only urinary homocitrulline excretion remained about 10 times higher than the normal values whereas the other amino acids in his serum and urine appeared to be within the normal range. After an oral load of lysine on a normal protein intake, several abnormal findings were observed. That is, clinically he had episodes of irritability, vomiting, and coma caused by ammonia intoxication. Biochemically, levels of citrulline and arginine in his serum and the urinary homocitrulline excretion rate continued to increase and arginase in the blood cells was markedly depressed. Blood cell arginase, which showed lower activity than that of control subjects, particularly on a normal protein intake, was extremely inhibited by lysine in the in vitro experiment. The citrulline tolerance curve after the load of L-citrulline was found to be normal on a low protein intake. Iysine:NA D-oxidoreductase activity in the liver was near the lower limits of the control values. The activity of argininosuccinate synthetase (A rgSS) was reduced to $22 \%$ of the control values. Arginase activity was also reduced.

\section{Speculation}

Hyperlysinemia, hypercitrullinemia, and massive homocitrullinuria found in our patient may be due to a partial defect of ArgSS, which has affinity for both citrulline and homocitrulline. We speculate that impairment of ammonia disposal participates in the deficiency of ArgSS as well as arginase.

A case of congenital lwine intolerance with periedic ammonia intoxication was first reported by (olombo et al. (8) in 1904 The patient. a 3-month-old girl. had been suffering from episodes of somiting. comal comsulsions, and failure to thrive since birth. In another report (7), these atuthors postulated that the caluse of hyperlysinemia was an impairment in the degradation of lysine due to a partial defect of lysine:NAD-oxidoreductase in the liver and that ammonia detoxication was impaired by hyperlysinemia which alcts als a competitive inhibiter on arginalse. The activities of the ureal cyele enzyme in the liver of the patient were normal. No other case has since heen reported during the past 10 years.

Recently we (17) reported an 18 -year-old mentally and physically retarded boy, suffering from anorexia and vomiting from 2 months of age. ()ur calse closely resembles (olombos. hut the specific findings of the former were ahnormally high concentra- 